\title{
Who Sells Out?: Petra Haden in the Age of Mechanical Reproduction
}

\author{
Marianne Tatom Letts \\ Independent scholar \\ marianne@illuin.org
}

\begin{abstract}
In 2005, Petra Haden released her version of The Who Sell Out, notable for the meticulousness and creativity with which she mimicked the various instruments on the album, and for the fact that she produced the project with an eight-track recorder and only her own voice. This article examines the ways in which Haden's interpretation of the classic album elevates it into the realm of "high art" while retaining its status as a commodity within the realm of popular music. Although the Who's original recording (1967) was one of the first concept albums, its unification comes not through a storyline or characters, as with other albums of that era, but through the foregrounding of its existence as a commodity. Radio jingles for both real and fake products are interspersed among the genuine commodities of pop songs, and the cover art features the Who in fake advertisements. Haden includes the jingles and even the cover artwork in her interpretation, but the changes she makes through generating every sound with her voice provide a level of unification that the original album does not possess. Haden's live reinterpretation (with her band the Sellouts) casts doubt on what constitutes the "authentic" version of the album, since the current lineup of the Who (two surviving members and various supporting musicians) no longer performs the material. Ultimately, Petra Haden Sings: The Who Sell Out functions as an art project that goes beyond the original album's intent.
\end{abstract}

Keywords: concept album, authenticity, Petra Haden, the Who, commodity

\section{Introduction}

The critical theorist Walter Benjamin (1935) has famously stated that, in the age of mechanical reproduction, in which artworks are replicated and disseminated on a large scale, the act of copying an original artwork both diffuses its meaning and decontextualises it. Reproducing an artwork can separate it from its original intended meaning. With dissemination comes decontextualisation. Replicating an artwork in one's own voice, such as creating a cover version of a pop song, both reproduces the original and changes it in a way that mass mechanical reproduction (such as burning CDs or downloading songs from iTunes) does not. This individualistic reinterpretation both brings the artwork to a different mass audience and allows for different types of connections to be formed between the audience, the artist, and the original artwork as well as the new one. The original artwork does not necessarily lose its primary meaning, however, and the new version may actually boost sales of the original and bring it to the attention of people who may not have previously known of its existence. Regardless of meaning, both versions of the artwork retain their 
status as a commodity within the realm of popular culture. In this article I will look at Petra Haden's 2005 reinterpretation of The Who Sell Out (MCA, 1967) and examine the ways in which it differs from that album and reinterprets the original artist's intent. Whereas the Who's album was an art-school-inspired project turned commercial, Haden's commercial release was received by and large as an art project by virtue of its unusual production and lack of singles, thus reclaiming in a sense the intent, or at least the inspiration, behind the original album.

\section{The Who Sell Out}

The Who's original 1967 recording was one of the first concept albums, but its unification comes not through a cohesive storyline or characters, as with other albums of that era, including the Who's own Tommy (1969) and Quadrophenia (1973), but through the foregrounding of its existence as a commodity. Radio jingles for both real and fake products are interspersed among pop songs, the "real" commodity. The album opens with a morning jingle for the pirate-radio station Radio London, by then defunct, and then segues into the first of many pop numbers. Some of the jingles were sung by the Who, but many of them were produced by PAMS Productions (Dallas, TX) for the real Radio London, an offshore station that had been shut down in August 1967. The Who were sued for copyright infringement for their use of the jingles, and a settlement was later reached (The Who Sell Out, 2007). Pete Townshend had initially thought of devoting an entire album side to advertisements but also wanted to "pay tribute to the recently silenced pirates, a censorious act that [he] regarded as an assault on British youth and rock and roll" (Dougan, 2006, pp. 91-92). The radio jingles both emphasise the album's playful nature and remind the audience of the state censure of pirate radio (p. 96). Dougan (2006, p. 109) states:

For Sell Out to maintain its conceptual consistency, the packaging had to articulate the notion, with tongue planted firmly in cheek, that the band was indeed "selling out". It needed to be funny and smart, slightly crass but in a manner that reinforced its pop art intentions and "[embraced the] world [of advertising], in all its mind-wrenching, sometimes stomach-churning contradictions and disarray" (quote from Dave Marsh, The Who Sell Out, 1995).

Townshend (Harrington, 2005) recalls that

until we came up with the idea of collecting all the disparate material we had as a spoof radio show, it felt like there was no record ready. . . . We were short of material and desperate not to have to go back into the studio again. . . . The format provided the answer. It also provided the sleeve design.

The cover artwork of The Who Sell Out was designed by David King (later the art director of the Sunday Times Magazine) and Roger Law (who went on to the political satire Spitting Image; see Dougan, 2006, p. 111), and features members of the Who appearing in ads for the products sung about on the album. Townshend holds a can of Odorono deodorant under his arm; Roger Daltrey sits in a tub of Heinz Baked Beans; Keith Moon holds a tube of Medac acne cream to his cheek; and John Entwistle is dressed as a brawny caveman for a Charles Atlas bodybuilding course. Photographer David Montgomery, notable for his portraits of many state figures as well as his "iconic images of the sixties" (Montgomery, 2010), produced "Sell Out's oversized photos, in the pop art tradition of emphasising advertising's vulgarity, [which] burst forth from their frames screaming, 'Buy this, now!'” (Dougan, 2006, p. 111). Included next to each photo was "fake ad copy that read like slightly surreal, imagist poetry ... metaphorically reinforcing the connection between pop art and consumer culture" (p. 112). The "ad" for Odorono (The Who Sell Out, 1967) reads: 
Replacing the stale smell of excess with

the sweet smell of success,

Peter Townshend, who, like nine out of ten stars, needs it. Face the music of the day with Odorono, the all-day deodorant that

turns persperation [sic] into inspiration.

Thus, the original album blurs the lines between art and commodification, producing a commercial product - a pop album - that promotes a commercial enterprise - a radio station as well as the band - through fake advertisements for real products.

The Who's album was also a result of Townshend's exposure at art school to the pop-art movement, including Gustav Metzger's theories of auto-destruction (art that either destroys itself, by virtue of its materials, or that is destroyed by the artist; see Metzger, 1960, and Smith, 1999, p. 14) as well as the 1962 TV documentary Pop Goes the Easel, directed by Ken Russell, who would later direct Tommy (Dougan, 2006, p. 33). Townshend stated in 1965 that "we stand for pop art clothes, pop art music, and pop art behaviour. This is what everybody seems to forget - and we don't change offstage. We live pop art" (quoted in Dougan, 2006, p. 36). Townshend also embraced the playful aspects of pop art, stating that with this album (which Smith calls "classic camp"; 1999, p. 18) he "wanted to change the fact that so many fans take us so seriously" (interview with Paul Nelson, quoted in Barnes, 1982, p. 47; see Dougan, 2006, n17, p. 125) as well as its commercial aspects. Dougan (2006, p. 23) states that Townshend "openly acknowledged that, in business terms, the dichotomy between art and commerce was false, art was commerce and as such could be analysed as a piece of pop art with multitudinous entry points". Moreover, by "successfully adopting and contextualising images that are "purloined from mass culture [and placed into] a fine art context', Sell Out is considerably more than a glib advertising put-on" (Dougan, 2006, p. 20; quote from Finch, 2001, p. 23). In other words, the Who took elements of pop art (which itself used elements from mass culture to create fine art) and used them to create high art in the form of a recorded art object (though when considered against classical music, pop music has traditionally been considered the lower art form).

The slightly later progressive-rock movement sought to align itself with "high art" by adopting elements from Western art music, such as orchestral arrangements and a multi-movement narrative that treated lyrics as poetry. Dougan (2006, pp. 1819) states that Sell Out was

not simply the apotheosis of the rock concept album (the majority being bloated, pretentious, pseudo-literary wankfests) ... [it] unashamedly celebrates the act of selling out in an exuberant, sensationalistic, and uncritical way, marking it as a prime example of pop art, and an early example of rock postmodernism.

Thus, the album's unifying themes including "'selling out' to advertising, a fond farewell to the era of offshore/pirate pop music broadcasting, the rock album as pop art, and the dynamic tension created by the nexus of American and British popular culture" (Dougan, 2006, p. 20). Smith (1999, p. 66) describes the album as the band's attempt to

have it both ways: the band could keep up with the times by producing a concept album and hang on to its youthful identity through humor - a humor that also advanced the rebellious, anti-establishment themes associated with the Who's image. 
Wilkerson (2009, p. 93) adds that the album

holds a mirror up to reality . . . a rock'n'roll mirror, something that gives you a totally distorted picture while revealing the truth. If you can't get your mind around that paradox ... . you aren't gonna have nearly as much fun with this album as it has to offer, and you must have missed the Sixties.

These views of the Who's album cast it as both a document of the era in which it was produced and a nostalgic look at the days of youthful rebellion by pirate broadcasters. Yet the album also expresses a cynicism that not only is it a commodity, produced to be sold to the consumer audience, but its producers, the Who, are also a commodity, even though they revel in that status.

\section{Petra Haden Sings: The Who Sell Out}

Born in 1971, Petra Haden is one of triplet sisters born to noted jazz bassist Charlie Haden. She learned to play the violin as a child and has performed or recorded with groups including the Decemberists and Green Day. She has also sung backup vocals with artists from Everclear to Bette Midler. As the biography on Haden's official website (2009) states, her early

love of instruments enabled her to provide unique voices to the notes she sang, re-creating the sounds of the instruments with her own voice, in pop, classical, jazz, blues, or any other idiom or genre one cares to name. She developed complex arrangements in her head and could interpret a wide variety of ecclectic [sic] sounding music.

Haden's first solo album, Imaginaryland (Win Records, 1996), featured "acappella [sic] voice collages" of both her own songs and covers (Haden, 2009). After that album's release, her friend and collaborator Mike Watt of the punk-rock group the Minutemen suggested she record The Who Sell Out in a similar fashion. Watt then lent her an eight-track recorder with the original album recorded onto one track and the other tracks left blank for her to record on. In 2005, Petra Haden released her own, a cappella version of the Who's classic album The Who Sell Out. Haden's rendition is notable for the meticulousness and creativity with which she mimics the various instruments on the original album, and for the fact that she produced the project using a multi-track recorder and only her own voice.

Petra Haden Sings: The Who Sell Out (Bar/None Records, 2005) includes the jingles and even the cover artwork of the original, displaying the singer in all four poses that the members of the Who had struck. Haden's appearance in the four ads echoes the replication of her voice in various personas throughout the album. She updates the ad copy to include herself instead of the Who, and the CD itself is stamped with a logo for Roto-Sound Strings, which a jingle on the album says will "hold your group together". The changes that Haden makes through generating every sound with her voice provide a level of aural unification that the original album does not possess. Not only does she reproduce the sounds of guitars and even brass band, she also provides her own rhythm track and all of the backing vocals. It is interesting to listen first to the guitar solo in the Who's version of "Armenia City in the Sky", then to Haden's version using only her voice (track one, after the opening jingle, about 2:30 into "Armenia"). Haden transforms the guitar tones into "wah, wah wahhh", along with higher "eeh" sounds and a quick "wawawa" to finish the solo. Whereas Pete Townshend is forever associated with the way he attacks and sometimes even destroys the guitar, Haden instead literally embodies it. She likewise embodies the percussion and bass, singing "tlin, tlin, tlin, tlin" to represent the 
cymbals at the break in "Rael" at 3:41 along with "dum, do dee da dum" underneath to represent the bass. Despite being multi-tracked out of necessity due to the single performer involved, the songs for the most part sound as though they could be replicated live by an ensemble, unlike many studio albums, particularly those of the later 1960s (Sgt. Pepper being a notable example, but also the progressive-rock bands that used complex keyboard arrangements that were difficult to reproduce live). Thus, Haden's rendition possesses a certain organic quality due to the extensive (and exclusive) use of the voice.

Haden stated in an interview with Creem magazine that prior to this project she had never even owned a Who album. She has said that she started the recording process with the song "I Can See for Miles" (the album's one single) because

that was the most popular song and it seemed like it was the easiest to do. ... I started ... just trying [to] sing all the parts like what I heard - which was really trippy because I heard all these backward guitars and I was thinking "How am I going to do that?" So I tried to make backward sounds with my voice (Bowe, 2005).

Haden has also said that on the album, she

tried to re-create notes and parts as closely as possible. . . But I didn't want to sing like the Who the whole time. On the song "Odorono" [which features an especially high vocal], I pretended I was Snow White. At the end of "I Can See for Miles", I added a weird dissonance [to the end of the "guitar solo"], like I was from the Bulgarian Female Vocal Choir (Anderman, 2005).

By exploring different sonic terrains, Haden puts her own imprint on the album, in the process changing the potential reception of it. Haden further stated that ". . . it took three years for me to do it, but I just did it as a side thing when I had time to do it. . . . I really just did it for fun, just to see what would happen" (Harrington, 2005). Thus, in contrast to the Who, Haden's commercial intent was an afterthought rather than a primary goal of the project.

\section{Jingles, Singles, and Personas}

In contrast to Haden's version of the album, from which no singles were released, the original The Who Sell Out contained one single - "I Can See for Miles" - which charted at number ten on the UK singles chart and number nine on the US Billboard charts (Meaty Beaty Big and Bouncy, 2007). The single was released in September 1967 in the United States and in October in the UK, pre-dating the album, which had a December release (The Who Sell Out, 2007). The Who's next several albums (Tommy, Who's Next, and Quadrophenia) would each have at least two singles, so it is somewhat unusual that the very album that most emphasised its status as a commodity produced the fewest number of singles. Whereas the Beatles' same-year release of Sgt. Pepper with no singles had forced listeners to consider the album itself as the commodity, The Who Sell Out offered both the single and the album as commodities. Releasing a single in order to create buzz for an album that comes out shortly afterward is still a typical practice in pop music. Those who like the single may buy the album in order to hear more of the artist's work, and those who buy the album initially may buy the single as well, in order to hear (consume) it on its own. Whereas in the heyday of the Who, the single could be played as a 45 record at a dance party or in a jukebox, as well as on the radio, today's albums might feature iTunes releases of singles for listeners to create their own playlists. Thus, the single has retained its status as a commodity despite the change in technology over the past forty-plus years. 
Table 1. Track Listing - Petra Haden Sings: The Who Sell Out. (Jingles are italicised; pop jingles are underscored; track placement noted as "The Who" is from the 1995 [MCA] CD version of The Who Sell Out.)

1: Days of the Week - Armenia City in the Sky (The Who puts jingle here)

2: Radio London - Heinz Baked Beans - More Music

3: Mary Anne with the Shaky Hand - Premier Drums

4: Odorono (The Who puts jingle here)

5: Radio London - Tattoo - Church of Your Choice

6: Our Love Was - Pussycat - Roto-Sound Strings

7: I Can See for Miles (The Who puts jingle here)

8: Charles Atlas - I Can't Reach You

9: Medac

10: Relax - Roto-Sound Strings

11: Silas Stingy

12: Sunrise

13: Rael

14: Track Records (The Who puts it at the very end of the extended CD)

\section{Pop songs}

Armenia City in the Sky

Mary Anne with the Shaky Hand

Tattoo

Our Love Was

I Can See for Miles

I Can't Reach You

Relax

Silas Stingy

Sunrise

Rael

Pop jingles

Heinz Baked Beans

Odorono

Medac

The songs on The Who Sell Out can be divided into three categories: pop songs, jingles, and what I have called pop jingles - pop songs that function as jingles by virtue of their subject matter (see Table 1). The song "Odorono", for example, tells the sad tale of a singer whose audition was ruined by her body odour. If only she had used Odorono, she would have won the part. The radio jingles, most of which I have assigned titles based on their subject matter, bookend the album and also occur between many of the songs. On the original album, the effect is that of listening to a radio station and being constantly subjected to ads. Indeed, Townshend had purportedly wanted to sell this space between songs to real advertisers (Harrington, 2005). On Haden's version, however, since she sings all of the material herself, the jingles and singles blur into one another due to (and perhaps contributing to) the continuity of the musical texture. The original album features some bleedover from the jingles into the pop songs, but in this instance the effect is simply that of a radio deejay starting to play one recording before the other has finished. On Haden's 
version of the album, although some tunes do segue into others, the effect is not the same as that of cutting off a pop song with an ad, as sometimes happens on the radio. The progression from the pop song "Our Love Was" (track six) into two jingles (which I have labelled "Pussycat" and "Roto-Sound Strings") and then into "I Can See for Miles" (track seven) illustrates this effect. As shown in Table 1, I have noted that Haden's version of the album often places the jingles at the beginnings of tracks, whereas the $1995 \mathrm{CD}$ version by the Who places them at the ends. An area for further investigation would be whether the original LP separated the jingles from the other songs, but even then the question would remain of whether this was the band's artistic decision or simply a choice made for convenience by the production team. Looking at the track listing overall is perhaps more productive, as it shows the relative placement of singles versus radio jingles versus pop jingles. Despite the fact that Haden retains the same overall placement of the songs, her version of the album sounds much less like a radio station's playlist, since her multi-tracked voice is used for all the sounds on the album. The human voice, particularly hers, is indeed versatile, but it is a poor match for the diversity found in brass choir versus electric guitar versus bass and drums. In unifying the album by homogenising its sounds, Haden detracts from the original album somewhat, though it is possible that she may have won the Who new fans who were attracted by the novelty of her version, then decided to buy the original album for comparison.

\section{Gender}

Another striking aspect of Haden's album is that she does not change the lyrics to the songs, even those which are gendered male. One example is "Tattoo", on which she sings "Now I'm older, I'm tattooed all over, my wife is tattooed too". The song presents a tale of the protagonist and his brother, who have an argument over "what makes a man a man", deciding finally that they must get tattoos to prove their manhood. The chorus states: "Welcome to my life, tattoo, I'm a man now, thanks to you". Hearing Haden sing these lyrics presents a cognitive dissonance because of her feminine voice, although Roger Daltrey's original featured a similarly light tone with a higher falsetto backing vocal. As Mosser (2008) points out, cover versions exist for a variety of reasons: to duplicate, to reinterpret, to send up in ironic fashion, or to parody (see Mosser's article for a bibliography of other sources on cover versions). Typically when artists do not change the gender in their cover versions, they are playing with gender stereotypes, such as on K. D. Lang's playful duet with Roseanne Cash on "You Ain't Woman Enough to Take My Man" (Country Music: A New Tradition, 1988), notable because Lang is a lesbian and thus probably not in competition for Cash for eligible men. Haden's lack of re-gendering, however, encourages the listener to experience the album as simply music, going beyond the original album's intent. Haden stated that, in recording the album, "I wasn't always paying attention to lyrics. Now l'm coming across people who are kind of insulted that I got some of the words wrong ..." (Harrington, 2005). Her words give the impression that she considered the album more as pure music. Daltrey's toying with gender in such songs as "Acid Queen" (from Tommy, 1969) and "I'm a Boy" (which was released as a single in 1966 and features lyrics about a boy whose mother refuses to admit his male gender) could be read as a proxy for Townshend's musings about his own bisexuality, which Townshend has discussed in various interviews. The other songs on The Who Sell Out either feature a third-person narrative ("Odorono", "Silas Stingy", "Medac") or use the gender-neutral "you" and "I" instead of "he" or "she". "Mary Anne with the Shaky Hand" is ambiguous enough to not cause cognitive dissonance in the listener, as the lyrics simply state what Mary Anne's shaky hands "have done to a man", rather than to the singer him- or herself. Edward T. Cone (1974, p. 18) notes, speaking of musical compositions in general, that 
the persona of each composition is uniquely created by and for that composition. And because ... the complete musical persona embraces both vocal and instrumental components, the composer's persona [that is, the persona specific to that musical work] governs words as well as music.

Thus, the persona of the song itself remains constant despite the song's performance by a different artist, presumably regardless of gender.

The question remains of whether the meaning of the original album The Who Sell Out is lost through its replication by Petra Haden. If we consider the original as an album from which several singles could have been released (although only one was) that would earn the Who money and recognition, then indeed the album as recorded and released by Haden has been stripped of its context, discounting the listeners who might be inspired to buy the Who's original album after hearing Haden's and thus fulfil the album's original commercial intent. However, if we consider also the possibility that the original Who album functioned as a parody, an art project gone commercial, then we must give closer examination to Haden's recording - does it too function as a parody of commercialisation, or does it become an art piece akin to a pure, "classical" work? On the surface Haden seems to reinscribe the album's original meaning by replicating its cover artwork, yet she also appears to downplay the content or change it into something new (purely musical) by not changing the gendered lyrics. The lack of singles (despite the availability of all fourteen tracks on iTunes) negates the possibility of the album functioning in the same commercial fashion as the original did and forces us to treat it as a complete artwork.

\title{
Reception and Authenticity
}

Reception of Haden's album has been divided between those who viewed her creation as a new level of authenticity (foregrounding the means of production) and those who saw it as more of an individualistic endeavour paying homage to the original without being slavish in its efforts. Stylus magazine (Kahrl, 2005) wrote:

While Haden is no Rahzel [member of the Roots famous for his beat-boxing skills], her approximations come close enough to the actual feel of the original, while retaining the spirit of the human voice. This is the crucial element to the whole effort in the end.

It is questionable why the "human voice" would be so crucial to maintain, given the varied instrumentation of the original. The emphasis on the voice assigns the authenticity to Haden herself, owner of that voice, rather than to the album. Rolling Stone (Fricke, 2005) stated:

\begin{abstract}
Petra's dedication to the original score backfires in the untouchable thunder crack of "I Can See for Miles"; her parakeet-army voices are no match for the Who's pop-art pow. But Haden's tender might in "Our Love Was" and "I Can't Reach You" taps an almost feminine sadness and delicacy in Pete Townshend's songs rarely heard outside his home demos.
\end{abstract}

Townshend's home demos would, undoubtedly, be part of some bonus "collectible" edition that only diehard fans would purchase. Rolling Stone's mention of these demos is the mark of an insider, keeping a secret from the masses. The repackaging of classic albums with bonus tracks appeals to the desire to attain insider status.

Entertainment Weekly (Adams, 2005) reported that Haden "plans to expand the franchise, recording Petra Goes to the Movies, on which she'll reinterpret (read: mimic) film scores and themes". Thus far this franchise has not seen daylight, so it is 
possible that $E W$ made the assumption based on an offhand or tongue-in-cheek remark that Haden made in the interview. Pitchfork (Loftus, 2005) sums up Haden's effort as "She uses suggestion instead, and a fan's emulation, and her own sense of humour, too; she makes something that loves its predecessor but has no intention of resembling it exactly". These assumptions of Haden's intent, that she was both a fan of the album and wanted to create a project that would express her love of it, are erroneous, in that Haden has stated that she wasn't familiar with the original before Mike Watt challenged her to replicate it. One could read her decision to release the album as a cynical one based on making money off it, but it is equally likely that she simply wanted to release a product that seemed like a natural progression from her first album, and that she was encouraged to do so by friends in the industry or her record company.

A final reaction was that of simply noting and admiring the album's quirkiness. In addition to Rolling Stone's description of Haden's "parakeet-army voices", Slate (Hus, 2005) wrote that Haden's

\begin{abstract}
tribute to the Who's playful 1967 album is alluring, with multi-tracked hums, meows, purrs, yowls, and bah-bah-bahs subbing for all the "proper" instruments. ... The focused chug and windmill guitar of "I Can See for Miles" get redone in the style of a scatterbrained barbershop quartet, while the already-trippy "Armenia City in the Sky" sounds even stranger with Haden's howls and birdcalls approximating Pete Townshend's backwards guitar.
\end{abstract}

Even Townshend himself (Anderman, 2005) has stated that Haden's recording forced him to re-imagine his own work, nearly forty years after its release:

I was a little embarrassed to realise I was enjoying my own music so much, for in
a way it was like hearing it for the first time.... What Petra does with her voice
is challenge the entire rock framework: the traditions, the processes, the decor,
the accessories, the entirety of the established dynamics of traditional pop-rock.
$\ldots$. When she does depart from the original music she does it purely to bring a
little piece of herself - and when she appears she is so very welcome.

Thus Townshend sees Haden's album not as an attempt to emulate the original but rather as a challenge to it, and one on which she made her personal mark by diverging from the original - creating a new authenticity through the use of her voice.

Another common mark of authenticity is an artist's ability to replicate a recording live, either exactly as recorded or acoustically reinterpreted, as in the series of "unplugged" concerts that various artists gave on MTV in the 1990s. Whereas the Who (at least in their early period) for the most part were able to perform their album material - even such pieces as the eight-minute mini-opera "A Quick One, While He's Away" (from A Quick One, 1966) - live, without hiring additional personnel, Haden assembled a ten-woman a cappella choir called the Sellouts (including her two triplet sisters, thus replicating herself, in a sense) to reproduce her Sell Out album live in Los Angeles as part of the "Sound" series produced by the Society for the Activation of Social Space through Art and Sound (SASSAS). The live treatment of the album's material by both Haden's ensemble and the Who heightens the contrast between Haden's art project and the present-day arena-rock spectacle of the Who. Haden received a grant from the Durfee Foundation, which provides funding for the arts in the LA community, in order to perform her album live. According to the foundation's website (Durfee Foundation, 2005), Haden received $\$ 2500$ to hire "four additional singers to a choir, to engage a conductor and additional rehearsal for the a cappella musical performance of Petra Haden sings 'The Who Sell Out', at the Schindler House in Los Angeles in June 2005". In contrast, the Who's own tours in recent decades have typically included stadiums and a full range of extra live musicians, sound technicians, and roadies as 
well as a variety of merchandise for attendees to purchase, thus further commodifying the band. The band's 2008 tour, undertaken by surviving members Daltrey and Townshend, allegedly brought the band $\$ 100$ million (Froelich, 2008).

Haden's live performances, by contrast, fall more naturally into the classical or art-music realm. A YouTube video of the Sellouts' performance shows a group of women wearing evening attire arrayed around microphones on a minimally decorated stage. Haden stands conducting in the middle, next to her sisters. The audience remains attentive but restrained. Videos of the Who's live performances on the "WhoTube" portion of the band's website show elaborate stage decorations, a screaming Roger Daltrey, and guitarist Pete Townshend windmilling his arms. Audience reaction is more enthusiastic and raucous, befitting a rock band. Peak-era live performances by the Who emphasised the sexuality of Daltrey's bare chest and buckskin fringe jacket, displaying his raw energy and showcasing his voice. When people think of the Who, they might recall Townshend's frenzied guitar smashing, but it is the power of Daltrey's voice (animating Townshend's lyrics) that has given the band such longevity and perhaps its authenticity. A recent article on Daltrey's preparation for a solo North American tour emphasises his voice as the source for his commodification. Daltrey (Graff, 2009) has consistently imagined his role in the Who as simply that of a conduit for Townshend's lyrics, and he has stated that he needs to keep his voice supple in order to use it as an instrument for the Who's future recording sessions or any gigs that Townshend might plan:

... sadly, l'm not the writer that Townshend is. One genius is enough in a band.

... You just have to be there for him if he needs you. That's my function. I'm just an instrument for him, and ... I'm quite happy with that.

In contrast to the Who's continual touring in support of their older work, Haden moved from the Sell Out project to another relatively small-scale recording with her father, her sisters, and other family members, called Charlie Haden Family \& Friends (Rambling Boy, Decca, 2008). The group has played live at various festivals worldwide but has not undertaken the kind of global-dominance tour for which the Who and other rock bands are known. According to Petra Haden's website (2009), she and the Sellouts are working on new material to perform live, and she is recording a new a cappella solo album. Thus, for Haden, the conceit of an album produced using only her voice goes beyond simply the gimmick of The Who Sell Out. The Sellouts have evidently moved past performing just material by the Who, despite the broad range of styles on albums such as The Who Sell Out and Tommy; a National Public Radio feature (Dye, 2006) calls them "unclassifiable. . . . Their music is so varied that one category can't suffice". Such a statement is unlikely to be made about the Who. Perhaps Haden and the Sellouts have recognised that a broader appeal lies in moving beyond the interpretations of only one artist's work, changing the initial gimmick into something more sustainable over time.

\section{Reproduction and Replication}

Benjamin (1935) has stated that the reproduction of an artwork also changes the reaction of the masses to that artwork. In the past an album functioned as a simulacrum of a live performance, but today the relationship is nearly the opposite, with live performances functioning mostly in support of album and merchandise sales. Theodor Adorno (1938) posited that the recording of an album fetishises it over a live performance of the same work, but we could theorise that Haden's live performance actually liberates the commodity by enacting it as an interactive artwork rather than as simply an item for sale. The audience is afforded the opportunity to relate to Haden onstage and in person rather than as a faceless voice on the recording. Haden's naming of the live ensemble as the Sellouts draws the audience's 
attention back to the status of the album (and of the ensemble itself) as a commodity and also functions as an ironic commentary on the act of making money off the original recording by touring live (although Haden's handful of live dates pales in comparison to the incessant touring by the surviving members of the Who).

The French economic theorist Jacques Attali (1985, p. 85) has noted that "people originally intended to use the record to preserve the performance, and today the performance is only successful as a simulacrum of the record". Cone (1974, p. 117) also notes that

Recordings . . encourage the attitude that what one is hearing is religiously fixed ... the reading as well as the text. As a result it is not uncommon to find a standard recording accepted by many as the composition, from which all other interpretations are considered to some extent deviant.

In John Philips's words (2009, p. 165), Jean Baudrillard's simulacrum is "an image or semblance of something, rather than the thing itself. And so to simulate something is to assume a false appearance". But, given the multiple layers of production and creative input involved in creating a studio recording, even the original object is a simulacrum of some abstract artistic concept.

It is rare today for a band at the national level to tour without having first released a product that they can then simulate live (Baudrillard's second-order simulation, "the order of production, which is in fact always a form of reproduction in signs that incessantly signify their own productivity"; Phillips, 2009, p. 168). Even bands at the regional level often offer recordings for sale at their live performances, and it is possible that they earn the bulk of their money this way. The question arises as to whether the live performance of Haden's ensemble functions as a simulacrum of her own album or of the original, which was probably never performed live in its entirety by the Who. This live reinterpretation also calls into question Attali's notion of the replica supplanting the original as well as what constitutes the "authentic" version of the album. Advances in technology and the continued unearthing and remixing of "bonus material" as well as new liner-note essays historicising and recontextualising "classic" rock albums make the idea of one authentic artwork even more slippery. Charles Levin (1996, p. 191) states that "a simulation is not so much an attempt to resemble something in appearance as to reassemble it from 'within', algorhythmically. ..." Thus both Haden's album and the Who's live performance are attempts to reproduce not the original album but some ideal version or abstract model of it that exists only in the mind. Benjamin $(2008$, p. 22) states that technical reproduction can bring out hidden aspects of a work in new settings that were inaccessible to the original (e.g., hearing a symphony performance in the living room versus the concert hall). The

authenticity of a thing is the quintessence of all that is transmissible in it from its origin on, ranging from its physical duration to the historical testimony relating to it. . . . what is really jeopardised when the historical testimony is affected is the authenticity of the object, the weight it derives from tradition.

In Haden's case, the original abstracted work is almost irrelevant, as "the work reproduced becomes the reproduction of a work designed for reproducibility" (p. 24). That is, her album attempts to replicate a recording rather than a live performance, and the reference point for the audience is that original recording.

In June 2009 the Who released a new deluxe edition of The Who Sell Out that expands the album to two discs and features several alternate mono and stereo versions of the original songs and jingles as well as bonus tracks. According to the product description on Amazon.com (2009), disc one of this new edition features the original stereo versions plus seventeen bonus tracks, while disc two contains the original mono versions and ten bonus tracks. The release also features a twenty- 
eight-page booklet with period ads and outtakes from the photo sessions for the original album. Amazon.com currently lists over twenty versions of the "original" The Who Sell Out, including several on vinyl, one of which includes, according to the product description, "an authentic reproduction of the 'Psychedelic Poster' included in original pressings of this title which are now nearly impossible to find". By continually repackaging the original album, the remaining members of the Who are reinforcing its status as a commodity by "selling out" to the same base of fans who will collect every iteration of a musical work in hopes of possessing it completely.

In a new kind of "selling out", Haden was commissioned in 2009 to record songs for three Toyota Prius (hybrid) commercials, including a cover of the Bellamy Brothers' 1976 hit "Let Your Love Flow". The songs are immediately recognisable as Haden's work to anyone who is familiar with her The Who Sell Out. The Prius's light environmental impact is depicted in the accompanying commercials, which feature a landscape formed entirely of people dressed in appropriate colours to mimic the blue sky, green trees, orange sun, and white clouds. Building the song using only Haden's voice mimics the use of people-as-environment. Haden's commercials provide an ironic link to the Who's licensing of many of their songs, including several for the CSI television franchise and particularly the song "Bargain", which was used in a commercial for the Nissan Pathfinder. The use of "Bargain" was meant to emphasise the car's cheap price tag, recontextualising the original, which Townshend describes as a song that "expresses how much of a bargain it would be to lose everything in order to be one with God" (Who's Next, 2007). Townshend sees no conflict with the use of his songs for commercial purposes, regardless of the mismatch between the lyrics and the products sold. He has stated:

\footnotetext{
We knew our generation would become the greatest consumers of all time: I hoped to become part of the satirical self-critique that I sensed would follow. . . . Selling music now to advertising agencies who want to use nostalgia or other triggering to attract attention to their products is a natural part of what l've always done. I've always sold my music. First act of Philistinism in my view was selling it to that bunch of reprobates called the Who. From such depths, one can only rise (Harrington, 2005).
}

Thus Townshend both acknowledges the commercialisation of his own art project and states that that was his intent all along. Townshend's attitude stands in contrast to that of artists such as Radiohead, who appear to struggle with the idea of selling their music as a commodity, challenging the listener instead to place a value on their work with the "pay what you like" system used to market their 2008 release In Rainbows (Letts, 2010). Townshend instead revels in the commercial potential for his work, selling and reselling it - and himself, on tour. By contrast, Haden (Anderman, 2005) claims not to have been thinking of The Who Sell Out as a commodity during the recording process: "I was sure no one but Mike Watt would hear it. I was not thinking about what Pete Townshend would think". Despite the album's status as a commodity, critics largely treated it as an eccentric art project, reclaiming Haden's original objective.

\section{Conclusions}

The difference in artistic intent is less relevant than the difference in the reception of the two albums' audiences. Benjamin (2008, p. 39) states:

The masses are criticised for seeking distraction in the work of art, whereas the art lover supposedly approaches it with concentration. In the case of the masses, the artwork is seen as a means of entertainment; in the case of the art lover, it is considered an object of devotion. 
Because Haden's album was received by the "masses" as an artwork, rather than simply a commercial product as the Who's album had been, it was returned to the realm of high art for which Townshend initially conceived it (that is, as a pop-art project rather than simply a commodity). Haden also returns to the original recording as a source, without any of the bonus tracks added to the later rereleases, reclaiming not only the original, pre-commercial intent, but also the original running order of the tracks. Intent may be embodied in the artwork without being received that way by the consumer; Haden's version is seen as "high art" by virtue of the quirkiness of its production despite its content being fundamentally similar to the original. It is impossible for an artist working within the capitalist culture to avoid both producing and becoming a commodity him- or herself. Regardless of any ironic intent, the artist "sells out" simply by producing the commodity. Despite such noble goals, then, in the end Petra Haden Sings: The Who Sell Out both retains the original album's status as a commodity, further foregrounding this status through her live presentation of the work, and reinterprets it as an art project worthy of public support and subsidy. Rather than producing an artwork meant to be bought and sold, regardless of how "ironic" the packaging seems, she treads lightly in the Who's footsteps, selling the album only incidentally, after creating the art project for herself.

\section{Acknowledgements}

Thanks to the reviewers of the IASPM@Journal as well as the audience members at the IASPM 2009 conference in Liverpool for their insightful comments and suggestions.

\section{References}

Adams, Jason. 2005. 'Pete Loves Petra'. Entertainment Weekly, issue 811, 18 March, <http://www.ew.com/ew/article/0,,1037012,00.html>

Adorno, Theodor. 1938. 'On the Fetish-Character in Music and the Regression of Listening', originally published in Zeitschrift für Sozialforschung, vol. 7.

Anderman, Joan. 2005. 'She Opened Her Mouth and the Who Came Out: Petra Haden Re-Creates Sell Out, Note for Note'. Boston Globe, 13 March, $<$ http://www.boston.com/news/globe/living/articles/2005/03/13/she_opened_her_mou th_and_the_who_came_out/>

Attali, Jacques. 1985. Noise: The Political Economy of Music, University of Minnesota Press, Minneapolis.

Barnes, Richard. 1982. The Who: Maximum R\&B. Eel Pie Publishing, London.

Benjamin, Walter. 1935 [2008]. 'The Work of Art in the Age of Its Technological Reproducibility' in Jephcott, Edmund; Livingstone, Rodney; Eiland, Howard et al. (trans.); Jennings, Michael W.; Doherty, Brigid and Levin, Thomas Y. (eds.). The Work of Art in the Age of Its Technological Reproducibility, and Other Writings on Media. Belknap Press of Harvard University Press, Cambridge, MA, and London.

Bowe, Brian. 2005. 'Petra Haden Sells Out'. Creem, March, <http://www.creemmagazine.com/_site/BeatGoesOn/PetraHaden/SellsOut001.html>

Cone, Edward T. 1974. The Composer's Voice, University of California Press, Berkeley and Los Angeles.

Dougan, John. 2006. The Who Sell Out, Continuum, New York and London. 
Durfee Foundation. 2005. <http://www.durfee.org/programs/arc/recipients2005.html> Dye, David. 2006. 'Petra Haden and the Sellouts: Unclassifiable'. World Cafe, 22 November, <http://www.npr.org/templates/story/story.php?storyld=6525998>

Finch, Christopher. 2001. 'London Pop Recollected' in Pop Art: U.S./U.K. Connections, 1965-1966. Hatje Cantz Verlag, Ostfildren-Ruit, Germany.

Fricke, David. 2005. Album review. Rolling Stone, 2 February.

Froelich, Paula. 2008. 'Pete \& Roger: Who Are You?' New York Post, 18 July, $<$ http://www.nypost.com/seven/07182008/gossip/pagesix/pete_roger_who_are_yo u_120385.htm>

Graff, Gary. 2009. 'Roger Daltrey Plots North American Tour'. Billboard, $<$ http://www.billboard.com/news/roger-daltrey-plots-north-american-tour1003999714.story\#/news/roger-daltrey-plots-north-american-tour-1003999714.story> Haden, Petra, and the Sellouts. 2005. Live performance, Ford Amphitheatre, Los Angeles, CA, 1 July, <http://www.youtube.com/watch?v=VNFoNBz9Dbs>

Haden, Petra. 2009. Official website, <http://petrahadenmusic.com>

Harrington, Richard. 2005. 'Petra Haden's A Cappella Who: Say What?' Washington Post, 10 April, <http://www.washingtonpost.com/wp-dyn/articles/A374002005Apr8.html>

Hsu, Hua. 2005. 'One-Man (and -Woman) Bands: The Joys of Flying Solo'. Slate, 20 May, <http://www.slate.com/id/2119161/>

The Hypertext Who. 2007. Liner notes to Meaty Beaty Big and Bouncy, <http://www.thewho.net/linernotes/MBBB.htm>

The Hypertext Who. 2007. Liner notes to Who's Next, <http://www.thewho.net/linernotes/WhosNext.htm>

The Hypertext Who. 2007. Liner notes to The Who Sell Out, $<$ <ttp://www.thewho.net/linernotes/WhoSellOut.htm>

Kahrl, Sarah. 2005. Album review. Stylus, 4 March, $<$ http://www.stylusmagazine.com/reviews/petra-haden/petra-haden-sings-the-whosell-out.htm>

Letts, Marianne Tatom. 2010. Radiohead and the Resistant Concept Album: How to Disappear Completely, Indiana University Press, Bloomington.

Levin, Charles. 1996. Jean Baudrillard: A Study in Cultural Metaphysics. Prentice Hall Europe, Hertfordshire, UK.

Loftus, Johnny. 2005. Album review. Pitchfork, 31 March, <http://pitchfork.com/reviews/albums/4005-petra-haden-sings-the-who-sell-out/> Marsh, Dave. 1995. Liner notes to The Who Sell Out.

Metzger, Gustav. 1960. 'Auto-Destructive Art Manifesto', <http://www.391.org/manifestos/1960metzger.htm>

Montgomery, David. 2010. <http://www.davidmontgomery.org/>

Mosser, Kurt. 2008. '“Cover Songs”: Ambiguity, Multivalence, Polysemy'. Popular Musicology Online, issue 2, <http://www.popular-musicologyonline.com/issues/02/mosser.html>

Phillips, John. 2009. 'Humanity's End' in Ryan Bishop ed. Baudrillard Now: Current Perspectives in Baudrillard Studies, Polity Press, Cambridge, UK, and Malden, MA. 
Smith, Larry David. 1999. Pete Townshend: The Minstrel's Dilemma, Praeger, Westport, CT.

Toyota Prius. 2009. <http://www.toyota.com/prius-hybrid/commercial.html> The Who. 2009. 'WhoTube',

$<$ http://www.thewho.com/index.php?module=movies\&movies_item_id=80>

Wilkerson, Mark. 2009. Who Are You: The Life of Pete Townshend, Omnibus, London and New York.

\section{Discography}

Haden, Charlie, Family \& Friends. 2008. Rambling Boy, Decca, 23 September, United States.

Haden, Petra. 1999. Imaginaryland, Win Records, 18 October, United States.

Haden, Petra. 2005. Petra Haden Sings: The Who Sell Out, Bar/None Records, 22 February, United States.

The Who. 1995. The Who Sell Out, MCA, 20 June, United States. 